\title{
Pengembangan Modul Berbasis Model Problem Based Learning (PBL) Pada Materi Aritmatika Sosial SMP
}

\author{
Fitriani Halik $^{1)}$, Thamrin Tayeb ${ }^{2)}$, Baharuddin ${ }^{3)}$, Nidya Nina Ichiana ${ }^{4)}$ \\ ${ }^{1,2,3}$ Fakultas Tarbiyah dan Keguruan UIN Alauddin Makassar \\ fitrianihalik960219@gmail.com ${ }^{l)}$, thamrin.tayeb@gmail.com ${ }^{2}$, baharuddin.abbas@uin-alauddin.ac.id ${ }^{3)}$, \\ nidyanina.ichiana@uin-alauddin.co.id ${ }^{4)}$
}

\begin{abstract}
Abstrak
Penelitian ini bertujuan untuk mengembangkan modul berbasis model Problem Based Learning (PBL) pada materi aritmatika sosial yang valid, praktis, dan efektif SMP Kelas VII. Jenis penelitian yang digunakan adalah research and development dengan model pengembangan Plomp. Produk yang dikembangkan yaitu modul berbasis model PBL materi aritmatika sosial. Subjek uji coba adalah 45 siswa kelas VII SMPN 2 Pattallassang. Instrumen yang digunakan adalah lembar validasi ahli, angket respons siswa dan guru, lembar observasi kemampuan guru mengelola pembelajaran, lembar observasi aktivitas siswa, dan tes hasil belajar. Berdasarkan hasil uji coba terbatas, diperoleh bahwa (1) Hasil validasi bahan ajar adalah 4,5 pada kategori sangat valid, (2) Praktis karena persentase rata-rata respons siswa adalah 82,6\% dengan kategori positif dan persentase rata-rata respons guru adalah 95\% dengan kategori sangat positif. (3) Efektif karena rata-rata kemampuan guru mengelola pembelajaran adalah 4,60 dengan kategori sangat baik, persentase rata-rata aktivitas siswa adalah 70,9\% dengan kategori baik, dan persentase ketuntasan belajar mencapai ketuntasan klasikal yaitu $88,9 \%$, tuntas secara klasikal. Sehingga disimpulkan bahwa berdasarkan uji coba terbatas, modul berbasis PBL pada materi aritmatika sosial memenuhi kriteria kevalidan, kepraktisan, dan keefektifan.
\end{abstract}

Kata Kunci: Modul, Problem Basic Learning (PBL), Sosial Aritmatika

\section{Pendahuluan}

Pendidikan memiliki peranan yang sangat sentral dalam meningkatkan kualitas sumber daya manusia. Undang-Undang Sistem Pendidikan Nasional (Sisdiknas), misalnya, menunjukkan akan peran strategis pendidikan dalam pembentukan SDM yang berkualitas. Karakter manusia Indonesia yang diharapkan menurut undang-undang tersebut adalah manusia yang beriman dan bertaqwa, berbudi pekerti luhur, berkepribadian, maju, cerdas, kreatif, terampil, disiplin, profesional, bertanggung jawab, produktif, serta sehat jasmani dan rohani. Upaya efektif untuk membentuk karakter manusia seperti ini dapat dilakukan melalui peningkatan kualitas pendidikan (Herman, 2007).

Mengingat peranannya yang sangat penting dalam proses peningkatan kualitas SDM, maka upaya peningkatan kualitas pembelajaran khususnya pada tingkat pendidikan dasar, memerlukan perhatian yang serius. Salah satu penyebab rendahnya kualitas pemahaman matematika siswa di SD dan SMP menurut hasil survey IMSTEP-JICA di kota Bandung adalah karena dalam proses pembelajaran matematika guru umumnya terlalu berkonsentrasi pada latihan menyelesaikan soal yang lebih bersifat prosedural dan mekanistis. Dalam kegiatan pembelajaran guru biasanya menjelaskan konsep secara informatif, memberikan contoh soal, dan memberikan soal-soal latihan. Kegiatan pembelajaran seperti ini tidak mengakomodasi pengembangan kemampuan siswa dalam pemecahan masalah, penalaran, koneksi, dan komunikasi matematis. Akibatnya, kemampuan penalaran siswa sangat lemah karena kegiatan pembelajaran yang biasa dilakukan hanya mendorong siswa untuk berpikir pada tataran tingkat rendah (Herman, 2007).

Berdasarkan hasil wawancara yang telah dilakukan pada guru matematika kelas VII SMPN 2 Pattallassang diperoleh informasi bahwa perangkat pembelajaran yang digunakan sudah bervariasi meliputi Rencana Proses Pembelajaran (RPP), bahan ajar, dan alat evaluasi. Bahan ajar yang digunakan ada yang berasal dari terbitan begitu pula dengan lembar kerjanya yang berpatokan dengan soal-soal yang terdapat di dalam buku paket. Selain itu, bahan ajar yang digunakannya juga sudah 
bervariasi, tetapi jika ditinjau dari segi kesesuaian kurikulum 2013, bahan ajar yang digunakan belum sesuai dengan tuntutan kurikulum, sehingga menyebabkan kreativitas guru terbatas dan kurang sesuai dengan karakteristik siswa. Selain itu, bahan ajar yang digunakan secara umum sudah bagus, akan tetapi isi dalam bahan ajar tersebut belum menjurus kepada suatu model pembelajaran yang dapat menunjang agar kemampuan pemecahan masalah siswa meningkat. Selain itu, guru juga dituntut dapat memilih model pembelajaran yang dapat memacu semangat siswa untuk secara aktif ikut terlibat dalam pengalaman belajarnya.

Salah satu upaya untuk mengatasi masalah di atas adalah dengan mengembangkan bahan ajar berupa modul dengan menerapkan model pembelajaran PBL ke dalam modul tersebut. Modul yang akan dikembangkan ini diharapkan mampu meningkatkan kemampuan pemecahan masalah yang dimiliki oleh siswa. Selain itu, salah satu materi pembelajaran yang memungkinkan siswa untuk dapat melihat masalah secara nyata adalah materi aritmatika sosial. Materi aritmatika sosial dipilih karena sesuai dengan model PBL, dengan penggunaan model ini akan lebih memudahkan siswa untuk menyelesaikan masalah yang berkaitan dengan soal aritmatika sosial.

Bahan ajar adalah segala bentuk bahan yang digunakan untuk membantu guru dalam melaksanakan kegiatan belajar mengajar di kelas. Bahan ajar yang dimaksud bisa berupa bahan tertulis maupun bahan tidak tertulis. Bahan ajar memungkinkan siswa dapat mempelajari suatu kompetensi atau kompetensi dasar secara runtut dan sistematis sehingga secara akumulatif mampu menguasai semua kompetensi secara utuh dan terpadu (Madjid, 2015). Bahan ajar dapat diartikan bahan-bahan atau materi pelajaran yang disusun secara lengkap dan sistematis berdasarkan prinsipprinsip pembelajaran yang digunakan guru dan siswa dalam proses pembelajaran. Bahan ajar bersifat sistematis artinya disusun secara urut sehingga memudahkan siswa belajar (Songkono, 2003). Menurut Mutiara dalam Yaumi (2012), bahan pembelajaran berfungsi sebagai materi sumber belajar utama bagi pembelajar jarak jauh, di mana mereka belajar dari materi cetak dan mempunyai pilihan untuk memilih dari berbagai media yang sesuai dengan kebutuhan dan keadaan belajar mereka, misalnya materi cetak, audio, casettes, video, program televisi, perangkat lunak CD-ROM, pelengkap berbasis jaringan, pembelajaran berbantuan komputer, dan program grafik audio.

Boud dan Feletti mengemukakan bahwa PBL adalah inovasi yang paling signifikan dalam pendidikan. Margetso mengemukakan bahwa kurikulum pembelajaran ini, mampu membantu untuk meningkakan perkembangan keterampilan belajar sepanjang hayat dalam pola pikir yang terbuka, reflektif, kritis dan belajar aktif. Kurikulum pembelajaran ini memfasilitasi keberhasilan memecahkan masalah, komunikasi, kerja kelompok dan keterampilan interpersonal dengan lebih baik dibanding pendekatan yang lain. Pembelajaran PBL merupakan penggunaan berbagai macam kecerdasan yang dilakukan untuk menghadapi segala sesuatu yang baru dan kompleksitas yang ada pembelajaran PBL biasanya terdiri dari lima tahapan utama yang dimulai dari guru memperkenalkan siswa dengan suatu situasi masalah dan diakhiri dengan penyajian dan analisis hasil kerja siswa (Rusman, 2016). Barrow mendefinisikan bahwa PBL sebagai pembelajaran yang diperoleh melalui proses menuju pemahaman akan resolusi suatu masalah. Masalah tersebut dipertemukan pertama-tama dalam proses pembelajaran. PBL merupakan salah satu bentuk peralihan dari paradigma pengajaran menuju paradigma pembelajaran. Jadi fokusnya adalah pada pembelajaran siswa dan bukan pada pengajaran guru (Huda, 2017).

Hal ini sejalan dengan penelitian yang dilakukan oleh Ridwan, Zulkardi, \& Darmawijoyo (2016) yang menyatakan bahwa berdasarkan proses pengembangan diperoleh juga bahwa prototipe perangkat pembelajaran yang dikembangkan memiliki efek potensial terhadap kemampuan 
pemecahan masalah, dimana hasil tes kemampuan pemecahan masalah siswa untuk kategori sangat baik $45,16 \%$, kategori baik 32,26\% dan kategori cukup 22,58\%.

\section{Metode Penelitian}

Jenis penelitian yang digunakan adalah penelitian dan pengembangan atau Research and Development $(R \& D)$. Research and Development adalah metode penelitian yang digunakan untuk menghasilkan produk tertentu, dan menguji keefektifan produk tersebut. Penelitian ini merupakan penelitian pengembangan yang mengacu pada model pengembangan Plomp. Penelitian ini menggunakan model pengembangan Plomp karena tahapan yang ada pada model ini sangat cocok dalam penelitian dan pengembangan perangkat pembelajaran yang akan dilakukan oleh peneliti. Model pengembangan Plomp merupakan model yang dikemukakan oleh Plomp yang terdiri dari 4 fase yaitu preliminary investigation (fase investigasi awal), design (fase desain), realization (fase realisasi) dan test, evaluation and revision (fase tes, evaluasi dan revisi). Subjek uji coba dalam penelitian ini adalah siswa kelas VII SMPN 2 Pattallassang. Instrumen pengumpulan data yang digunakan dalam penelitian ini adalah lembar validasi ahli, lembar observasi kemampuan guru dalam mengelola pembelajaran, lembar observasi aktivitas siswa, angket respons guru, angket respons siswa, dan tes hasil belajar (THB).

\section{Hasil}

Pengembangan modul matematika berbasis model pembelajaran PBL pada penelitian ini menggunakan model pengembangan Plomp yang terdiri dari 4 fase yaitu preliminary investigation (fase investigasi awal), design (fase desain), realization (fase realisasi) dan test, evaluation and revision (fase tes, evaluasi dan revisi). Penjelasan tahap-tahap pengembangan tersebut dijelaskan lebih lanjut sebagai berikut:

\subsection{Preliminary Investigation (Fase Investigasi Awal)}

Fase investigasi awal dilakukan untuk menentukan masalah dasar yang diperlukan untuk mengembangkan modul. Pada tahap ini dilakukan analisis teori pendukung bahan ajar, analisis kurikulum, analisis siswa, dan analisis materi ajar dengan cara mengumpulkan dan menganalisis informasi yang mendukung untuk merencanakan kegiatan yang akan dilakukan pada tahap selanjutnya.

Berdasarkan hasil wawancara yang telah dilakukan dengan guru matematika kelas VII di SMPN 2 Pattallassang diperoleh informasi bahwa perangkat pembelajaran yang digunakan sudah bervariasi meliputi RPP, bahan ajar, dan alat evaluasi. Bahan ajar yang digunakan ada yang berasal dari terbitan begitu pula dengan lembar kerjanya yang berpatokan dengan soal-soal yang terdapat di dalam buku paket. Selain itu, bahan ajar yang digunakannya juga sudah bervariasi, tetapi jika ditinjau dari segi kesesuaian kurikulum 2013, bahan ajar yang digunakan belum sesuai dengan tuntutan kurikulum, sehingga menyebabkan kreativitas guru terbatas dan kurang sesuai dengan karakteristik siswa. Mengenai hasil belajar siswa khususnya di mata pelajaran matematika memiliki nilai yang beragam, ada yang tinggi, sedang dan rendah. Akan tetapi lebih banyak siswa yang tidak mencapai standar kelulusan. Data yang ada menunjukkan bahwa rata-rata hasil belajar matematika siswa adalah 70 sehingga dapat ditafsirkan bahwa nilai KKM yang diperoleh siswa masih di bawah rata-rata dan belum memenuhi KKM yaitu 75. Adapun beberapa faktor yang menyebabkan siswa tersebut mendapatkan nilai matematika di bawah KKM yaitu motivasi belajar siswa masih rendah, kondisi lingkungan sekolah terutama sarana dan prasarana secara keselurahan belum memenuhi karena 
fasilitas pembelajaran masih kurang, kemampuan guru yang masih kurang baik dan kondisi pergaulan siswa yang kurang baik.

Berdasarkan hasil observasi yang telah dilakukan di SMPN 2 Pattallassang, peneliti melihat kegiatan proses belajar mengajar yang masih konvensional, kemudian bahan ajar yang digunakan secara umum sudah bagus, akan tetapi isi dalam bahan ajar tersebut belum menjurus kepada suatu model pembelajaran yang dapat menunjang agar kemampuan pemecahan masalah siswa meningkat. Selain itu, guru juga dituntut dapat memilih model pembelajaran yang dapat memacu semangat siswa untuk secara aktif ikut terlibat dalam pengalaman belajarnya. Setelah mengkaji dari beberapa literatur mengenai teori-teori yang cocok untuk digunakan, peneliti mendapat sebuah model pembelajaran yang sesuai dengan kurikulum 2013 dan juga dapat membuat siswa lebih mandiri dan lebih aktif menemukan konsep dari materi yang akan dipelajarinya. Model pembelajaran yang dimaksud adalah PBL. Model pembelajaran PBL dapat membantu siswa dalam menemukan konsep materi yang diajarkan.

Pada fase ini, dilakukan analisis kurikulum. Analisis kurikulum yang dimaksud adalah peneliti menganalisis kurikulum yang digunakan di sekolah tersebut. Berdasarkan hasil observasi yang dilakukan, peneliti mendapatkan bahwa kurikulum yang digunakan di sekolah tersebut adalah kurikulum 2013 revisi kurikulum 2016. Analisis siswa juga dilakukan pada fase ini. Siswa yang menjadi subjek penelitian ini adalah siswa kelas VII SMPN 2 Pattallassang tahun pelajaran 20182019. Pada analisis siswa, peneliti menelaah tentang latar belakang pengetahuan siswa dan tingkat perkembangan kognitif siswa. Hasil telah menunjukkan bahwa siswa kelas VII SMPN 2 Pattallassang telah mempelajari materi-materi penunjang ditingkat sekolah dasar (SD) sebagai materi prasyarat untuk mempelajari materi pokok aritmatika sosial SMP/MTs kelas VII. Jika ditinjau dari tingkat perkembangan kognitifnya, menurut Peaget siswa-siswi ini telah berada pada tahap operasi formal (umur 11-18 tahun). Artinya siswa sudah mampu berfikir abstrak, logis, dan kemampuan menarik kesimpulan. Namun, pada kenyataannya, di usia tersebut siswa masih memerlukan benda-benda atau masalah-masalah nyata dalam pembelajaran matematika. Kegiatan yang dilakukan dalam menganalisis materi adalah mengidentifikasi, merinci, dan menyusun secara sistematis materi-materi utama yang dipelajari siswa, selanjutnya materi tersebut disusun secara sistematis. Materi pelajaran dalam penelitian ini adalah materi aritmatika sosial dengan standar isi kurikulum 2013. Garis besar pada materi aritmatika sosial dengan indikator-indikator ketercapaian antara lain harga penjualan, harga pembelian, untung, rugi, diskon, bruto, tara netto, bunga tunggal dan pajak.

\subsection{Design (Fase Desain)}

Fase selanjutnya adalah fase desain, pada fase desain ini peneliti mulai merancang modul dengan menggunakan model PBL pada materi aritmatika sosial kelas VII. Pada fase ini, dirancang desain dan sistematika perangkat pembelajaran yang akan digunakan dalam pembelajaran yang mencakup beberapa aspek, yaitu:

Tahap pertama yang dilakukan adalah pemilihan format. Hasil Pemilihan format RPP disesuaikan dengan sintaks pembelajaran matematika berbasis model PBL yang didalamnya memuat kompetensi inti, kompetensi dasar, indikator, tujuan pembelajaran, materi ajar, penilaian, kegiatan pembelajaran, dan sumber bacaan. Pelaksanaan pembelajaran meliputi: model, pendekatan metode, dan alat sumber belajar. Skenario pembelajaran terdiri dari kegiatan pendahuluan, kegiatan inti dan penutup. Di dalam RPP khususnya pada kegiatan inti dimasukkan model PBL sedangkan format modul dan THB dibuat berwarna, teratur, rapi, terstruktur sehingga siswa akan tertarik, termotivasi dan mudah untuk belajar. 
Tahap kedua adalah pembuatan produk. Pada fase desain telah dirancang modul pembelajaran yang akan dibuat, kemudian pada tahap ini dimulailah pembuatan produk yang sesuai dengan struktur yang telah dirancang tersebut. Tahap pertama yaitu membuat sampul modul yang telah dirancang kemudian tahap kedua membuat isi modul yang strukturnya juga telah disesuaikan dengan struktur modul yang telah dirancang sebelumnya.

Tahap ketiga adalah membuat rancangan awal modul. Peneliti mencari informasi dari berbagai sumber terkait dengan cara membuat sampul modul. Melihat dari contoh sampul buku atau pun contoh sampul bahan ajar lainnya yang telah ada, sehingga peneliti bisa menghasilkan rancangan yang terlihat lebih bagus dan terlihat menarik dengan kombinasi warna dan gambar yang sesuai sehingga siswa tertarik untuk menggunakan modul sebelum melihat isi bahan ajar tersebut.

Pada rancangan isi, pemilihan dan penentuan bahan dimaksudkan untuk memenuhi salah satu kriteria bahwa suatu modul harus menarik dan dapat membantu siswa untuk mencapai kompetensi. Dengan demikian, modul dibuat sesuai dengan kebutuhan dan kecocokan dengan kompetensi dasar yang akan diraih oleh siswa. Dalam hal ini peneliti memilih modul dengan menggunakan model PBL pada materi aritmatika sosial kelas VII. Modul ini dirancang berdasarkan kurikulum matematika yang berlaku sesuai dengan jenjang pendidikan yaitu SMP/MTs. Modul ini berisi masalah nyata, materi aritmatika sosial, kegiatan belajar yang memuat sintaks model pembelajaran PBL, contoh soal, evaluasi pada setiap sub materi, rangkuman dan uji kompetensi yang terletak diakhir bab.

Modul ini dilengkapi dengan 5 langkah atau sintaks model pembelajaran PBL yang dituangkan ke dalam modul yaitu orientasi siswa pada masalah, mengorganisasi siswa untuk belajar, membimbing penyelidikan individual maupun kelompok, mengembangkan dan menyajikan hasil karya, dan menganalisis dan mengevaluasi proses pemecahan masalah. Di dalam modul ini, terdapat kata "Mengamati Masalah" merupakan bagian yang mewakili fase pertama dalam sintaks PBL yaitu orientasi siswa pada masalah. "Mari Berdiskusi" merupakan bagian yang mewakili fase kedua dalam sintaks PBL yaitu mengorganisasi siswa untuk belajar. "Menggali Informasi" merupakan bagian yang mewakili fase ketiga dalam sintaks PBL yaitu membimbing penyelidikan individu atau kelompok. "Membuat Laporan" merupakan bagian yang mewakili fase keempat dalam sintaks PBL yaitu mengembangkan dan menyajikan hasil karya. "Mari Berbagi" merupakan bagian yang mewakili fase kelima dalam sintaks PBL yaitu menganalisis dan mengevaluasi proses pemecahan masalah. Inilah yang merupakan ciri khas modul yang dihasilkan pada penelitian ini yang cukup berbeda dengan modul yang digunakan siswa sebelumnya di sekolah.

Tahap keempat adalah penyusunan instrumen penelitian. Instrumen yang digunakan dalam penelitian ini terdiri 3 aspek yaitu kevalidan, kepraktisan, dan keefektifan. Aspek kevalidan, terdiri dari lembar validasi modul, lembar validasi lembar angket respons siswa, lembar validasi lembar angket respons guru, lembar validasi lembar observasi aktivitas siswa, lembar validasi lembar observasi kemampuan guru mengelola pembelajaran, lembar validasi RPP, dan lembar validasi THB. Aspek kepraktisan, terdiri dari lembar angket respons guru dan lembar angket respons siswa. Aspek keefektifan, terdiri dari lembar observasi kemampuan guru mengelola pembelajaran, lembar observasi aktivitas siswa, dan THB.

\subsection{Realization (Fase Realisasi)}

Pada tahap pengembangan ini bertujuan untuk menghasilkan perangkaat pembelajaran matematika berbasis pendekatan kontekstual yang telah direvisi sehingga layak digunakan dalam penelitian atau diujicobakan. Kegiatan yang dilakukan pada tahap ini adalah: validasi ahli dan uji coba. 


\subsection{Test, Evaluation, and Revision (Fase Tes, Evaluasi, dan Revisi)}

Pada tahap validasi ahli, dilakukan validasi oleh ahli terkait modul yang telah dibuat pada fase realisasi. Validasi yang dilakukan oleh tim ahli pada validasi produk adalah validasi isi dari segi substansi, konstruk, bahasa dan praktikalitas. Kemudian validasi yang dilakukan oleh tim ahli pada validasi desain adalah yang berhubungan dengan tampilan fisik bahan ajar yaitu desain sampul, tampilan isi buku, konteks masalah dan gambar, dan kepadatan isi materi. Melalui pertimbangan ahli ini diharapkan kualitas produk yang dibuat dapat teruji secara teoritis dan rasional serta menarik baik dari segi tampilan fisik maupun tampilan isi materi. Validasi ini dilakukan dengan mendatangi langsung ahli untuk menilai dan memvalidasi produk yang dibuat dengan memperlihatkan rancangan desain dan diminta untuk menilainya sehingga selanjutnya dapat diketahui letak kelemahan dan kelebihannya.

Berdasarkan hasil analisis validasi yang telah dilakukan, data menunjukkan bahwa modul, RPP, THB, angket respons guru, angket respons siswa, lembar observasi aktivitas siswa dan kemampuan guru dalam mengelola peembelajaran menunjukkan rata-rata dari keseluruhan aspek adalah 4,5 sehingga berada pada kategori sangat valid karena setiap aspek pada setiap jenis lembar validasi berada pada inteval $4 \leq M \leq 5$. Selain itu, semua validator memberikan kesimpulan bahwa perangkat yang telah dikembangkan adalah baik dan dapat digunakan dengan sedikit revisi.

Proses validasi yang pertama kali di lakukan dengan mengajukan rancangan awal modul dengan menggunakan model pembelajaran berbasis PBL yang telah dikembangkan pada bagian awal kepada tim validator. Adapun deskripsi masukan yang diberikan oleh validator sebagai berikut:

Tabel 1. Hasil Validasi yang dilakukan pada Proses Validasi Pertama meliputi Saran-Saran dari Tim Validator

\begin{tabular}{|c|c|}
\hline Aspek & Saran Perbaikan \\
\hline Modul & $\begin{array}{l}\text { 1. Sampul yang digunakan masih perlu perbaikan. Usahakan bikin } \\
\text { sampulnya lebih kreatif lagi dan kriteria warna yang di gunakan } \\
\text { harus senada dengan isi modul } \\
\text { 2. Sebaiknya desain isi modul tidak memuat gambar animasi yang } \\
\text { tidak penting dan tidak menarik. } \\
\text { 3. Gambar yang terdapat dalam modul harus dicantumkan sumbernya } \\
\text { 4. Dalam setiap sub pokok bahasan harus memuat kegiatan yang } \\
\text { sesuai dengan sintaks pembelajaran berbasis PBL. } \\
\text { 5. Soal penyelesaian yang terdapat dalam modul terlalu panjang } \\
\text { penjelasannya sehingga orang akan cepat merasa bosan untuk } \\
\text { membacanya. } \\
\text { 6. Cari ide yang baik, agar modul ini efektif, menarik dan sesuai } \\
\text { dengan tema PBL. }\end{array}$ \\
\hline RPP & $\begin{array}{l}\text { 1. Kegiatan inti dalam RPP sebaiknya di sesuaikan dengan sintaks } \\
\text { pembelajaran PBL. Susunan subbab materi harus sistematis } \\
\text { 2. Sesuaikan dengan K13. }\end{array}$ \\
\hline Tes Hasil Belajar & $\begin{array}{l}\text { Soal-soal yang dibuat harus memenuhi semua indikator dalam } \\
\text { pembelajaran. }\end{array}$ \\
\hline Angket Respons Siswa & $\begin{array}{l}\text { Perbaiki beberapa kata-kata yang masih kurang jelas dan sesuaikan } \\
\text { dengan kaidah bahasa Indonesia. }\end{array}$ \\
\hline Angket Respons Guru & Usahakan kata-kata yang ada di dalamnya di sesuaikan dengan kaidah \\
\hline
\end{tabular}


bahasa Indonesia.

Lembar Observasi Sebaiknya aktivitas siswa terdiri dari 5 sintaks dalam pembelajaran Aktivitas Siswa problem based learning (PBL).

Lembar Observasi Perbaiki beberapa kata-kata yang masih kurang jelas dan sesuaikan Kemampuan Guru dalam dengan kaidah bahasa Indonesia.

Mengelola Pembelajaran

Proses validasi yang kedua dilakukan dengan mengajukan hasil revisi dalam proses validasi pertama sesuai dengan catatan yang diberikan pada proses validasi pertama kepada tim validator. Deskripsi masukan yang diberikan oleh validator sebagai berikut:

Tabel 2. Hasil Validasi yang Dilakukan pada Proses Validasi Kedua meliputi Saran-Saran dari Tim Validator

\begin{tabular}{ll}
\hline \multicolumn{1}{c}{ Aspek } & \multicolumn{1}{c}{ Saran Perbaikan } \\
\hline Modul & Sampul modul yang digunakan sebaiknya didesain lebih menarik lagi. \\
& Usahakan setiap kegiatan yang ada di dalam bahan ajar, disesuaikan \\
& dengan model pembelajaran PBL. \\
& Pada kegiatan inti, hilangkan aktivitas guru dalam menjelaskan materi. \\
RPP & Sintaks pembelajarannya harus sesuai dengan sintaks pembelajaran PBL \\
& dan menggunakan pendekatan saintifik \\
& Alokasi waktu pengerjaan soal harus disesuaiakan dengan banyak soal \\
Tes Hasil Belajar & yang dikerjakan. \\
\hline
\end{tabular}

Berdasarkan data di atas dapat disimpulkan bahwa rata-rata penilaian dari para ahli validator berada pada kategori "sangat valid" hal ini menunjukkan bahawa modul, RPP, THB, angket respons siswa, angket respons guru, lembar observasi aktivitas siswa, dan lembar observasi kemampuan guru dalam mengelola pembelajaran tersebut layak untuk diujicobakan. Pada uji coba terbatas, modul yang telah direvisi berdasarkan saran-saran dan masukan selanjutnya diujicobakan pada siswa kelas VII SMPN 2 Pattallassang. Uji coba tersebut dilakukan untuk melihat kepraktisan dan keefektifan modul yang dikembangkan.

Data kepraktisan diperoleh dari angket respons siswa dan angket respons guru. Angket respons siswa diberikan kepada 45 orang siswa kelas VII setelah mengikuti seluruh rangkaian pembelajaran dengan menggunakan modul berbasis model PBL pada pokok bahasan aritmatika sosial. Berdasarkan hasil analisis diperoleh bahwa persentase rata-rata respons siswa terhadap kegiatan pembelajaran dengan menggunakan modul memiliki nilai lebih besar dari $80 \%$. Dari keseluruhan aspek yang ditanyakan, presentasi respons siswa adalah $82,6 \%$. Angka tersebut berada pada interval $70 \% \leq R S<85 \%$ dengan kategori positif

Angket respons guru diberikan kepada guru setelah kegiatan mengajar dilaksanakan menggunakan modul berbasis PBL yang telah dikembangkan. Dari keseluruhan aspek yang ditanyakan terlihat bahwa total respons guru terhadap kegiatan pembelajaran dengan menggunakan modul memiliki nilai sebesar 95\%. Angka tersebut berada pada interval 85\% $\leq R S \leq 100$ dengan kategori sangat positif.

Data keefektifan diperoleh dari lembar observasi kemampuan guru dalam mengelola pembelajaran, lembar observasi aktivitas siswa dan THB. Tujuan analisis kemampuan guru dalam mengelola pembelajaran adalah untuk melihat sejauh mana kemampuan guru mengelola pembelajaran 
matematika dengan menggunakan modul berbasis PBL di kelas. Hasil pengamatan secara keseluruhan diketahui bahwa rata-rata skor kemampuan guru adalah 4,60 berada pada kriteria $(4,5 \leq T K G<5,0)$ yang artinya kemampuan guru dalam mengelola pembelajaran matematika dengan menggunakan modul berbasis PBL berada pada kategori sangat baik dan telah memenuhi salah satu komponen keefektifan.

Aktivitas siswa selama proses pembelajaran diamati berdasarkan 5 kriteria aktivitas siswa yaitu: (1) Siswa membaca dan mencermati konteks masalah yang ada dalam modul, (2) Siswa membentuk kelompok untuk menyelesaikan masalah yang ada dalam modul, (3) Siswa mendiskusikan jawaban dari permasalahan yang ada bersama dengan teman kelompoknya, (4) Siswa mempresentasikan/menanggapi hasil jawaban diskusi kelompok lain dan (5) Siswa menarik kesimpulan/rangkuman dari materi yang telah dipelajari. Berdasarkan hasil analisis, diperoleh persentase aktivitas siswa selama pembelajaran adalah 70,9\%. Angka tersebut berada pada interval $60 \% \leq \mathrm{P}<80 \%$ dengan kategori baik. Dengan demikian, aktivitas siswa menggunakan modul berbasis PBL yang diamati telah terpenuhi.

Berdasarkan hasil analisis tes hasil belajar diperoleh informasi bahwa tes hasil belajar yang diikuti oleh 45 orang siswa terdapat 40 siswa mendapat skor di atas KKM, dengan nilai KKM adalah 75. Siswa termasuk kategori sedang ada $11,1 \%$ sedangkaan siswa yang termasuk kategori tinggi sekitar 75,6\% dan yang termasuk kategori sangat tinggi adalah 13,3\%. Dengan demikian, dapat disimpulkan bahwa skor rata-rata hasil belajar matematika seluruhnya berada dalam kategori tinggi. Berdasarkan segi ketuntasan terdapat 40 orang dari 45 siswa yang memperoleh nilai 75 ke atas. Sedangkan 5 siswa memperoleh skor di bawah 75 .

\section{Pembahasan}

Penelitian dan pengembangan modul berbasis model PBL diawali dengan melakukan analisis terhadap siswa di SMPN 2 Pattallassang tentang masalah-masalah yang kerap terjadi. Berdasarkan hasil wawancara yang telah dilakukan dengan guru Matematika kelas VII di SMPN 2 Pattallassang diperoleh informasi bahwa perangkat pembelajaran yang digunakan sudah bervariasi meliputi RPP, bahan ajar, dan alat evaluasi. Bahan ajar yang digunakan ada yang berasal dari terbitan begitu pula dengan lembar kerjanya yang berpatokan dengan soal-soal yang terdapat di dalam buku paket. Selain itu, bahan ajar yang digunakannya juga sudah bervariasi, tetapi jika ditinjau dari segi kesesuaian kurikulum 2013, bahan ajar yang digunakan belum sesuai dengan tuntutan kurikulum, sehingga menyebabkan kreativitas guru terbatas dan kurang sesuai dengan karakteristik siswa. Selain itu, berdasarkan hasil observasi yang telah dilakukan disekolah tersebut, peneliti melihat kegiatan proses belajar mengajar yang masih konvensional, kemudian bahan ajar yang digunakan secara umum sudah bagus, akan tetapi isi dalam bahan ajar tersebut belum menjurus kepada suatu model pembelajaran yang dapat menunjang agar kemampuan pemecahan masalah siswa meningkat. Selain itu, guru juga dituntut dapat memilih model pembelajaran yang dapat memacu semangat siswa untuk secara aktif ikut terlibat dalam pengalaman belajarnya. Salah satu upaya untuk mengatasi masalah di atas adalah dengan mengembangkan modul dengan menerapkan model pembelajaran PBL ke dalam modul tersebut. Modul yang dikembangkan ini diharapkan mampu meningkatkan kemampuan pemecahan masalah yang dimiliki oleh siswa. Sebelum proses pengembangan dilakukan, telah ditetapkan kriteria kualitas modul yang dikembangkan untuk melihat sejauh mana keberhasilan produk yang dihasilkan, produk tersebut dikatakan berhasil apabila telah memenuhi tiga kriteria yaitu valid, praktis dan efektif.

Pengembangan bahan ajar yang dilakukan telah melalui serangkaian fase pengembangan model plomp mulai dari fase investigasi awal (preliminary investigation), fase desain (design), fase 
realisasi (realization/construct) dan fase tes, evaluasi dan revisi (test, evaluation and revision) sehingga menghasilkan sebuah bahan ajar berupa modul berbasis model pembelajaran PBL, artinya materi yang terkandung di dalam modul disusun sedemikian rupa sehingga sesuai dengan langkahlangkah model pembelajaran PBL. Hal ini menjadi karakter utama yang ingin ditunjukkan peneliti. Modul ini dirancang berdasarkan kurikulum matematika yang berlaku sesuai dengan jenjang pendidikan yaitu SMP/MTs. Modul ini berisi masalah nyata, materi aritmatika sosial, kegiatan belajar yang memuat sintaks model pembelajaran PBL, contoh soal, evaluasi pada setiap sub materi, rangkuman dan uji kompetensi yang terletak diakhir bab. Modul ini dilengkapi dengan 5 langkah atau sintaks model pembelajaran PBL yang dituangkan ke dalam modul yaitu orientasi siswa pada masalah, mengorganisasi siswa untuk belajar, membimbing penyelidikan individual maupun kelompok, mengembangkan dan menyajikan hasil karya, dan menganalisis dan mengevaluasi proses pemecahan masalah.

Model pembelajaran PBL dipilih tidak hanya berdasarkan masalah yang ditemukan di lapangan, namun juga memiliki beberapa keunggulan. Salah satu keunggulannya yaitu pemecahan masalah dapat menantang kemampuan siswa serta memberikan kepuasan untuk menemukan pengetahuan baru bagi siswa, dan melalui pemecahan masalah dapat mengembangkan kemampuan siswa untuk berpikir kritis dan mengembangkan kemampuan mereka untuk menyesuaikan dengan kemampuan baru. Selain itu, melalui pembelajaran PBL dapat membuat mahir dalam memecahkan dan mengambil solusi dari suatu masalah. Dalam kurikulumnya, juga dirancang masalah-masalah yang memotivasi untuk mendapatkan pengetahuan yang penting sehingga memiliki strategi belajar sendiri serta memiliki kecakapan berpartisipasi dalam kelompok diskusi.

Berdasarkan hasil uji kevalidan yaitu penilaian para validator, disimpulkan bahwa modul matematika berbasis model pembelajaran PBL serta insrtumen validasi lainnya telah memenuhi kriteria kevalidan. Meskipun sebelumnya telah dilakukan beberapa revisi sesuai saran yang diberikan oleh para validator. Berdasarkan hasil analisis validasi dari para validator, didapatkan hasil validasi pada beberapa instrumen kevalidan antara lain: modul dengan rata-rata 4,5; respons siswa dengan rata-rata 4,5; respons guru dengan rata-rata 4,5; kemampuan guru mengelola pembelajaran dengan rata-rata 4,5; aktivitas siswa dengan rata-rata 4,5; RPP dengan rata-rata 4,5 dan tes hasil belajar dengan rata-rata 4,5. Masing-masing instrumen kevalidan tersebut berada pada kategori sangat valid, dengan demikian, bahan ajar dan instrumen pendukungnya memenuhi kriteria kevalidan. Hal yang sama juga didapatkan dari bahan ajar yang dikembangkan oleh Rifai (2015) memenuhi kriteria kevalidan dengan skor validasi rata-rata 42,5 dari skor maksimal 52.

Bahan ajar dan lembar observasi serta lembar tes hasil belajar yang telah dinyatakan valid kemudian diujicobakan ke siswa untuk mengetahui kepraktisan dan keefektifan bahan ajar melalui data-data yang diperoleh dalam kegiatan ujicoba. Berdasarkan pembahasan sebelumnya yaitu pada uji keefektifan, Keefektifan bahan ajar dapat dilihat dari (1) kemampuan guru dalam mengelola pembelajaran, (2) aktivitas siswa dan (3) tes hasil belajar. Hasil analisis data dari komponenkomponen keefektifan tersebut yaitu rata-rata kemampuan guru dalam mengelola pembelajaran adalah 4,60 berada pada kategori sangat baik, persentase rata-rata aktivitas siswa adalah 70,9\% berada pada kategori baik, dan persentase ketuntasan belajar siswa berada pada kategori tinggi serta mencapai ketuntasan klasikal yaitu $88,9 \%$ siswa tuntas secara klasikal. Hal tersebut juga sesuai dengan teori yang dikemukakan oleh Arsyad (2016) bahwa bahan ajar memenuhi kriteria keefektifan apabila komponen-komponen keefektifan tercapai keseluruhan. Dari hasil uji coba yang dilakukan 
ketiga kriteria tersebut telah terpenuhi, dengan demikian, bahan ajar yang dikembangkan telah memenuhi kriteria keefektifan.

Kepraktisan bahan ajar dapat dilihat dari angket respons siswa dan angket respons guru. Angket respons guru dan angket respons siswa yang telah dianalisis menunjukkan respons yang positif terhadap bahan ajar yang digunakan. Hasil analisis data dari komponen-komponen kepraktisan tersebut adalah persentase rata-rata untuk respons siswa $82,6 \%$ berada pada kategori positif dan persentase rata-rata respons guru 95\% dan berada pada kategori sangat positif. Dengan demikian, bahan ajar yang dikembangkan memenuhi kriteria praktis. Hal yang sama juga didapatkan dari bahan ajar berupa modul yang dikembangkan oleh Achmaliya, Rosilawati, Kadaritna, \& Sunyono (2016), bahan ajar yang dikembangkannya memenuhi kriteria praktis, hal ini ditunjukkan dengan tanggapan guru dan siswa setelah menggunakan modul yang telah dikembangkan adalah positif.

\section{Kesimpulan}

Kesimpulan yang dapat ditarik dari penelitian ini adalah modul yang dikembangkan menggunakan model pengembangan plomp yaitu meliputi tahap preliminary investigation (fase investigasi awal), design (fase desain), realization (fase realisasi) dan test, evaluation and revision (fase tes, evaluasi dan revisi) untuk menghasilkan modul berbasis model PBL pada materi aritmatika sosial yang valid, praktis dan efektif. Kriteria valid dilihat berdasarkan hasil validasi perangkat pembelajaran berupa modul dengan rata-rata 4,5, respon siswa dengan rata-rata 4,5, respon guru dengan rata-rata 4,5, kemampuan guru mengelola pembelajaran dengan rata-rata 4,5, aktivitas siswa dengan rata-rata 4,5, RPP dengan rata-rata 4,5 dan tes hasil belajar dengan rata-rata 4,5. Masingmasing instrumen kevalidan tersebut berada pada kategori sangat valid, dengan demikian bahan ajar dan instrumen pendukungnya memenuhi kriteria valid. Kriteria praktis dilihat berdasarkan hasil analisis dari respon siswa dan respon guru. Hasil analisis data menujukkan bahwa persentase rata-rata untuk respon siswa adalah $82,6 \%$ berada pada kategori positif dan persentase rata-rata respon guru adalah $95 \%$ dan berada pada kategori sangat positif. Dengan demikian, modul yang dikembangkan memenuhi kriteria praktis. Kriteria efektif dilihat berdasarkan 3 indikator yaitu kemampuan guru dalam mengelola pembelajaran, aktivitas siswa dan tes hasil belajar. Hasil analisis data dari komponen-komponen keefektifan tersebut menunjukkan bahwa rata-rata kemampuan guru dalam mengelola pembelajaran adalah 4,60 berada pada kategori sangat baik, persentase rata-rata aktivitas siswa adalah $70,9 \%$ berada pada kategori baik, dan persentase ketuntasan belajar siswa berada pada kategori tinggi serta mencapai ketuntasan klasikal yaitu 88,9\% siswa tuntas secara klasikal. Dengan demikian, modul yang dikembangkan memenuhi kriteria efektif.

\section{Daftar Pustaka}

Achmaliya, N., Rosilawati, I., Kadaritna, N., \& Sunyono. (2016). Pengembangan Modul Berbasis Representasi Kimia pada Materi Teori Tumbukan. Jurnal Pendidikan dan Pembelajaran Kimia, 5(1), 114-127. Retrieved from http://jurnal.fkip.unila.ac.id/index.php/JPK/article/viewFile/12034/8603

Arsyad, N. (2016). Model Pembelajaran Menumbuh Kembangkan Kemampuan Metakognitif. Makassar: Pustaka Refleksi.

Herman, T. (2007). Pembelajaran Berbasis Masalah untuk Meningkatkan Kemampuan Berpikir Matematis Tingkat Tinggi Siswa Sekolah Menengah Pertama. EDUCATIONIST, 1(1), 47-56. Retrieved from http://file.upi.edu/Direktori/JURNAL/EDUCATIONIST/Vol._I_No._1Januari_2007/6._Tatang_Herman.pdf

Huda, M. (2017). Model-Model Pengajaran dan Pembelajaran. Yogyakarta: Pusataka Pelajar. 
Madjid, A. (2015). Pengembangan Modul Matematika pada Materi Garis dan Sudut Setting Pembelajaran Kooperatif Tipe Think Pair Share (TPS) untuk Siswa Kelas VII SMP. Universitas Islam Makassar.

Ridwan, R., Zulkardi, \& Darmawijoyo. (2016). Pengembangan Perangkat Pembelajaran Aritmatika Sosial Berbasis Problem Based Learning di Kelas VII SMP. Jurnal Elemen, 2(2), 92-115. Retrieved from https://www.researchgate.net/publication/322891340_Pengembangan_Perangkat_Pembelajara n_Aritmetika_Sosial_Berbasis_Problem_Based_Learning_di_Kelas_VII_SMP

Rifai, A. (2015). Pengembangan Bahan Ajar Berbasis Discovery Learning dengan Produk Poster Bergambar untuk Siswa SMA. Universitas Negeri semarang.

Rusman. (2016). Model-Model Pembelajaran. Jakarta: Raja Grafindo Persada.

Songkono. (2003). Pengembangan Bahan Ajar. Yogyakarta: FIP UNY.

Yaumi, M. (2012). Desain Pembelajaran Efektif. Makassar: Alauddin University Press. 